University of the Pacific

Scholarly Commons

$6-1-2020$

\title{
Impact of COVID-19 on dental education in the United States
}

\author{
Parvati lyer \\ University of the Pacific \\ Kalid Aziz \\ University of the Pacific \\ David M. Ojcius \\ University of the Pacific, California, dojcius@pacific.edu
}

Follow this and additional works at: https://scholarlycommons.pacific.edu/dugoni-facarticles

Part of the Dentistry Commons

\section{Recommended Citation}

lyer, P., Aziz, K., \& Ojcius, D. M. (2020). Impact of COVID-19 on dental education in the United States. Journal of Dental Education, 84(6), 718-722. DOI: 10.1002/jdd.12163

https://scholarlycommons.pacific.edu/dugoni-facarticles/463

This Article is brought to you for free and open access by the All Faculty Scholarship at Scholarly Commons. It has been accepted for inclusion in All Dugoni School of Dentistry Faculty Articles by an authorized administrator of Scholarly Commons. For more information, please contact mgibney@pacific.edu. 


\title{
Impact of COVID-19 on dental education in the United States
}

\author{
Parvati Iyer BDS, DDS | Kalid Aziz DDS, MS | David M. Ojcius PhD 잉
}

Arthur A. Dugoni School of Dentistry, University of the Pacific, San Francisco, California, USA

\section{Correspondence}

Parvati Iyer, BDS, DDS, Arthur Dugoni School of Dentistry, University of the Pacific, 155 Fifth Street, San Francisco, CA 94103, USA. Email: piyer@pacific.edu

\begin{abstract}
Dental institutions in the United States are reeling from the consequences of the novel SARS-CoV2 coronavirus, the causative agent of CODIV-19. As oral health care providers, we have been trained on prevention of aerosol transmissible diseases, but we are still grappling with many unknown factors regarding COVID-19. While the Centers for Disease Control and Prevention (CDC), American Dental Association (ADA), and local state agencies are releasing updates on guidelines for dentists and patients, no official information exists for dental institutions on how to effectively follow the recommended guidelines including "shelter in place" with social distancing to protect students, faculty, staff, and patients, and still ensure continuity of dental education. This article discusses the challenges that we face currently and offers some simple strategies to bridge the gaps in dental education to overcome this emergency.
\end{abstract}

\section{K E Y W O R D S}

coronavirus, COVID-19, dental education, education technology, e-learning, online learning, oral health, pandemic
During the current pandemic, the Occupational Safety and Health Administration (OSHA.gov) classified dentists in the very-high-risk category because of the potential of exposure to coronavirus through aerosol-generating procedures. ${ }^{1,2}$ What are dental schools doing during this pandemic to prevent transmission to dental students? How are dental schools managing students and their general anxiety about redesigned classes, patient care, inability to fulfill clinical requirements for graduation, and concerns for safety? Being in an environment that is changing by the minute, it is imperative that dental schools make appropriate and timely modifications to their teaching and learning methods to ensure continuity of education, and implement interim policies and protocols to protect our staff, students, faculty, and patients. This paper makes simple recommendations to dental educators and administrators that could be easily adopted to tide over the COVID-19 emergency and be better prepared for similar disruptions in the future.

\section{1 | BACKGROUND}

Though there have been 2 outbreaks with coronaviruses in the recent past-causing severe acute respiratory syndrome (SARS), which emerged in late 2002 and disappeared by 2004; and Middle East respiratory syndrome (MERS), which was transmitted from camels and camel products to humans ${ }^{3-6}$ - there is not much research on the impact of the pandemic caused by the novel coronavirus on dental education. Patil et al. ${ }^{7}$ wrote about SARS and its effect on medical education. Park et al. ${ }^{8}$ discussed the measures taken by a dental school in South Korea to prevent infection with MERS. Kharma et al. ${ }^{9}$ measured the awareness of dental students regarding the MERS outbreak. The most recent article, by Meng et al. ${ }^{10}$, discussed the impact of COVID-19 on dental and oral medicine in China. However, a comprehensive description of the impact of COVID-19 on dental education in the United States has not been reported yet. 


\section{2 | CHALLENGES FOR DENTAL SCHOOL ADMINISTRATION}

The biggest challenge for the administration of dental schools is trying to balance the important task of safeguarding the health of students, faculty, and patients, while keeping track of the changing environment and local or national policies, and at the same time, ensuring that there is continuity in the education of the students.

Although there are many similarities between the 67 dental schools in the United States in managing the COVID-19 pandemic from an academic perspective, variations are inevitable based on local agencies' policies and recommendations, the extent of spread of infection, and availability of faculty and other resources. In addition, the administration is required to submit a report to the Commission on Dental Accreditation (CODA) on their program with respect to distance learning, alternative assessment, and curricular modification. CODA, under the guidance of the United States Department of Education, will evaluate the Policies, Procedures, and modifications to the Standards in the Accreditation Report and will circulate the temporary guidelines to the dental programs in coming weeks. ${ }^{11}$

\section{3 | CHALLENGES IN TEACHING AND LEARNING}

With the surge of confirmed COVID-19 cases in the United States and stay-at-home orders implemented in many states, dental schools have had to manage the increasing anxiety among students, faculty, and patients. As oral health care providers, we need to educate and enforce the need to flatten the curve of the pandemic, in order to avoid overwhelming hospitals with a large flux of patients. ${ }^{12}$ The American Dental Education Association (ADEA) has taken the lead with regard to recommendations for teaching modalities like online education and other creative teaching methods, connecting faculty and administrators on ADEA Connect ${ }^{13}$ to share ideas and resources to implement in these unusual times.

Most dental schools in the United States have suspended clinical activities except for dental emergencies, and some are practicing social distancing in their preclinical simulation laboratory activities. For those schools that do not have this option, simulation with mannequins is very difficult to teach online considering the time, manpower, and technology needed for instruction. Virtual reality systems and haptic technology, if already available, are not portable and therefore cannot be used at this time.

Most of the didactic classes at the dental schools in the United States have been converted to remote instruction according to adea.org. Each dental school must consider the institutional, operational, teaching, and learning capacity in determining what types of modifications to the educational program would be successful during this time.

The biggest challenge has been to postpone direct patient care, which is a key component of the dental curriculum. ${ }^{14}$ No virtual sessions can duplicate the close experience with patients. Extramural rotations have also been cancelled.

Faculty and administrations are struggling to balance the need to comply with state and governmental agencies' recommendations, while keeping students engaged and motivated to continue to learn remotely in this dynamic environment. Because of indefinite stay-at-home orders in place, school calendars and schedules are affected; licensing exams have been delayed or cancelled. Because of this, the responsibility may fall upon the dental school to certify the competency of the graduating dental students. It may be crucial to design an assessment that includes the skills, knowledge, aptitude, and behavior needed to be a competent dentist. One solution could be to use a multidisciplinary Objective Structured Clinical Exam (OSCE) combined with a written exam for the seniors, similar to the Canadian OSCE Licensing exam. ${ }^{15}$ Resources could be shared among schools to create this exam.

Graduation ceremonies may be delayed, cancelled, or moved online depending on the situation locally. Family members could be entrusted with the task of donning the gown and cap for their sons/daughters and joining the ceremony through Zoom or WebEx.

Because of the disruption in routine patient care due to the pandemic, residency programs around the nation may have to evaluate the residents based on clinical care completed until the start of the pandemic and certify the residents to graduate. One solution is to have peer reviews of their clinical work along with a panel of supervising faculty.

Technology can be very useful but, for many faculty and students, it still involves a learning curve. Since faculty are scrambling to learn and teach online during this emergency, there is no time to evaluate and choose between synchronous and asynchronous online teaching and learning, to relay to students distance education etiquettes and protocols, yet still be flexible enough to deviate from the original plan of content delivery.

\section{4 | DISTANCE EDUCATION AS A SOLUTION}

Technology in teaching and learning should be employed when appropriate after adequate training of faculty in remote teaching. The success of e-learning depends on the attitudes and interactive teaching styles of the faculty, as well as on the experience and attitudes of students with regard to technology. ${ }^{16}$ Though there may be challenges in e-learning in dentistry, ${ }^{17}$ educational institutions should not wait for an 
emergency to include online courses or elements of e-learning in courses and measure their effectiveness from a pedagogical, organizational, teaching, and learning perspective. Distance education expectations should be made clear to students, and included in the course description with extra points allotted for participation in online seminars, journal clubs, and casebased discussions.

In choosing the type of educational methodology to be utilized for distance learning, it is important to understand the differences between synchronous and asynchronous teaching. Synchronous teaching is preferred when peer interactions would be beneficial and when critical thinking skills are taught at the level of a novice. Asynchronous teaching could be adopted to facilitate collaborative learning but may need to be moderated by experienced faculty. Blended learning that has both synchronous and asynchronous elements may be effective for teaching integrated content and its application in clinical scenarios, as in dental emergencies. ${ }^{18}$ Flipped classroom techniques require students to review online modules before participating in seminars. Problem-based learning (PBL) approaches could ensure comprehension of important concepts and build on critical thinking.

Didactic classes are the easiest to manage online, since they can be incorporated in flipped classroom methodologies that are effective in dental education. ${ }^{19}$ VoiceThread (VT) is an excellent cloud-based program that allows videos and PowerPoint to be integrated in a presentation. ${ }^{20}$ Faculty can also moderate discussions on VT. The enhanced features of this software allow for collaboration and peer learning among students that can be synchronous or asynchronous. ${ }^{21,22}$

Preclinical didactic and case-based exercises could be delivered as videos with embedded quiz questions using a platform such as EDpuzzle. ${ }^{23}$ EDpuzzle is an innovative tool that converts video watching into a student-centered activity by increasing student engagement. It allows faculty to embed timestamped questions with instant feedback in a clinical video for students to answer while watching the video.

Clinical videos that enhance the learning experience can also be created by faculty. Since it can be time-consuming to create these videos, it might be beneficial to share these resources with other schools. ${ }^{24}$

Assessment strategies can include formative exams on learning management systems like Canvas ${ }^{25}$ and summative exams on ExamSoft, ${ }^{26}$ with third-party online proctoring by ProctorU, ${ }^{27}$ Honorlock, ${ }^{28}$ Respondus Monitor, ${ }^{29}$ and Examity. ${ }^{30}$ Small group discussions using WebEx can be used to stimulate active discussion on the concepts learned, with PBL to encourage critical thinking. For example, seminars on COVID-19 could be included in the distance learning experience to facilitate open discussion and address anxiety among faculty and students. Patients should have access to pertinent information in the school's website that explains the measures taken by the dental schools to ensure their safety.
Since many dental schools are operating differently due to the COVID-19 pandemic, this could be a good opportunity for the school administration to invest in online training for faculty so they could create online modules for their courses. ${ }^{31}$

According to section 5.5 in the CODA standards, dental schools must provide professional services, including dental emergencies, to patients of record. ${ }^{14}$ Due to the COVID-19 pandemic, most of the schools have suspended clinical care by students except for dental emergencies for active patients that are seen by faculty or residents.

This is a unique challenge for the dental profession due to the nature of the work environment, where high aerosols and droplets are generated during routine procedures. Standard precautions are not enough to prevent the spread of the coronavirus, especially during the incubation phase of COVID19. ${ }^{10}$ Soon after the outbreak began in the United States, the ADA recommended that clinics suspend all routine or elective treatment, and manage dental emergencies and urgent care to mitigate the burden on the health care system (Table 1). The first step in this protocol is to screen the patients, to evaluate whether their case is in fact an emergency. The next step is to determine if the dental facility is equipped with appropriate protective equipment to handle the procedures. ${ }^{32}$

Meng et al. ${ }^{10}$ reported that dental emergencies required immediate dental care, and the use of rubber dams and highvolume ejectors could minimize aerosol production during dental treatment. According to this report, ${ }^{10}$ appointments with patients with respiratory disease should be scheduled at the end of the day in order to minimize the risk of nosocomial infection. Isolated rooms with good ventilation or negatively pressurized rooms would be more appropriate for patients with suspected cases of COVID-19.

Other recommendations included strategies for conserving personal protective equipment (PPE) to ensure that adequate equipment is available for patients whose appointments are most urgent. The CDC has made available resources to assist and support healthcare professionals during the current pandemic. ${ }^{33}$ Dentists could also report shortages of PPE to the FDA at deviceshortages@fda.hhs.gov.

The administration of dental schools could also reassess the existing policies in the clinic and protocols in place for emergencies and learn how to improve them in the event of another emergency in the future.

\section{5 | RECOMMENDATIONS FOR THE EDUCATIONAL INSTITUTION}

Telecommuting should be recommended for faculty during the indefinite shelter-in-place order. Clear policies and protocols should be conveyed to the faculty, so there is no confusion with regard to expectations and responsibilities. Special considerations should be given to female faculty and 
T A B L E 1 American Dental Association guidelines determining dental procedures ${ }^{32}$

\begin{tabular}{|c|c|c|}
\hline Dental emergency & Urgent care & Routine/nonurgent care \\
\hline $\begin{array}{l}\text { Uncontrolled bleeding } \\
\text { Cellulitis or a diffuse soft tissue } \\
\text { bacterial infection with } \\
\text { intra-oral or extra-oral swelling } \\
\text { that potentially compromises the } \\
\text { patient's airways } \\
\text { Trauma involving facial bones, } \\
\text { potentially compromising the } \\
\text { patient's airways }\end{array}$ & $\begin{array}{l}\text { Severe dental pain from pulpal inflammation } \\
\text { Pericoronitis or third-molar pain } \\
\text { Surgical postoperative osteitis or dry socket dressing } \\
\text { changes } \\
\text { Abscess or localized bacterial infection resulting in } \\
\text { localized pain and swelling } \\
\text { Tooth fracture resulting in pain or causing soft tissue } \\
\text { trauma } \\
\text { Dental trauma with avulsion/luxation } \\
\text { Dental treatment cementation if the temporary } \\
\text { restoration is lost, broken or causing gingival } \\
\text { irritation extensive caries or defective restorations } \\
\text { causing pain suture removal denture adjustments } \\
\text { on radiation/oncology patients denture } \\
\text { adjustments or repairs when function impeded } \\
\text { replacing temporary filling on endo access } \\
\text { openings in patients experiencing pain snipping or } \\
\text { adjustments of an orthodontic wire or appliances } \\
\text { piercing or ulcerating the oral mucosa }\end{array}$ & $\begin{array}{l}\text { Initial or periodic oral examinations and } \\
\text { recall visits, including routine } \\
\text { radiographs } \\
\text { Routine dental cleaning and preventive } \\
\text { therapies } \\
\text { Orthodontic procedures other than those } \\
\text { to address acute issues (e.g., pain, } \\
\text { infection, trauma) } \\
\text { Extraction of asymptomatic teeth } \\
\text { Restorative dentistry including treatment } \\
\text { of asymptomatic carious lesions } \\
\text { Aesthetic dental procedures }\end{array}$ \\
\hline
\end{tabular}

staff and families with young children due to lack of childcare options. Faculty should hold meetings online to reprioritize goals, reorganize course materials, and obtain training on remote teaching. Department chairs should reassure faculty regarding their capacity to adapt to this emergency.

There is a great deal of anxiety among students who must adjust to new methods of educational instruction and are fearful for their safety and health. The school administration can offer psychological counseling for students to cope with the situation. ${ }^{34}$ Attendance and grading policies and submission of assignments should be modified to reduce anxiety among the students. Open communication, ${ }^{8}$ readily available accurate information, and quick dissemination of important decisions could help to allay fears of the unknown in students, faculty, and staff, as well as the patients.

School administration can create a link on the school website for students, faculty, and staff with answers to frequently asked questions, and can address concerns regarding operations, schedules, and calendars. Patients should be able to access information on the school website to help overcome backlogs in communication with students and the clinic.

Finally, given that the school closure will undoubtedly affect faculty scholarly productivity, especially when some research projects need to stop for months, schools should be tolerant with regard to promotion and tenure decisions for faculty.

\section{6 | CONCLUSION}

Multiple agencies, universities, and companies are working diligently to develop faster testing, and better measures for prevention and treatment of COVID-19 infection. Dental schools should focus on re-evaluating and reprioritizing their policies and protocols and include a detailed contingency plan in case of future pandemics. This experience should also prompt dental schools to re-evaluate their competencybased education, incorporate variations of distance learning permanently in their curricula, invest in haptic technology to improve psychomotor skills and also in faculty training for teaching through technology. Extramural rotations and interprofessional education should be strengthened in the curricula to enable dental students to have the ability to make an impact in the community and help during such a crisis. We hope that this article may shed some light on the gaps in preparedness of many dental schools for such pandemics in the future, thus minimizing disruptions to the training of students and residents.

\section{ORCID}

David M. Ojcius PhD (D)

https://orcid.org/0000-0003-1461-4495

\section{REFERENCES}

1. Educational Debt. American Dental Education A. https:// www.adea.org/GoDental/Money_Matters/Educational_Debt.aspx. Accessed April 18, 2020.

2. U.S. Department of Labor, Occupational Safety and Health Administration. Guidance on preparing workplaces for COVID-19. OSHA 3990-03 2020. Accessed April 18, 2020.

3. Karlamangla S. SARS killed hundreds and then disappeared. Could this coronavirus die out?Los Angeles Times. February 18, 2020. https://www.latimes.com/california/story/2020-02-18/sarscoronavirus-china-epidemic. Accessed April 18, 2020. 
4. Adney DR, Letko M, Ragan IK, et al. Bactrian camels shed large quantities of Middle East respiratory syndrome coronavirus (MERS-CoV) after experimental infection. Emerg Microbes Infect. 2019;8(1):717-723.

5. Banerjee A, Baid K, Mossman K. Molecular pathogenesis of Middle East Respiratory Syndrome (MERS) coronavirus. Curr Clin Microbiol Rep. 2019;6(3):139-147.

6. Khudhair A, Killerby ME, Al Mulla M, et al. Risk factors for MERS-CoV seropositivity among animal market and slaughterhouse workers, Abu Dhabi, United Arab Emirates, 2014-2017. Emerg Infect Dis. 2019;25(5):927-935.

7. Patil NG, Chan Y, Yan H. SARS and its effect on medical education in Hong Kong. Med Educ. 2003;37(12):1127-1128.

8. Park SW, Jang HW, Choe YH, et al. Avoiding student infection during a Middle East respiratory syndrome (MERS) outbreak: a single medical school experience. Korean J Med Educ. 2016;28(2):209217.

9. Kharma MY, Alalwani MS, Amer MF, Tarakji B, Aws G. Assessment of the awareness level of dental students toward Middle East Respiratory Syndrome-coronavirus. J Int Soc Prev Community Dent. 2015;5(3):163-169.

10. Meng L, Hua F, Bian Z. Coronavirus Disease 2019 (COVID-19): emerging and future challenges for dental and oral medicine. J Dent Res;2020. 22034520914246.

11. Accreditation updates: COVID-19. American Dental Association, Commission on Dental Accreditation. https://www.ada.org/en/ coda/accreditation/accreditation-news. Accessed April 18, 2020.

12. Newman K. Flattening the coronavirus curve and the importance of social distancing. US News \& World Report. March 18, 2020. https://www.usnews.com/news/healthiest-communities/articles/ 2020-03-18/coronavirus-how-social-distancing-can-flatten-the-curve. Accessed April 18, 2020.

13. ADEA. Community rules and etiquette. https://connect.adea.org/ community-rules. Accessed April 21, 2020.

14. Accreditation standards for dental education programs. American Dental Association. https://www.ada.org/ /media/CODA/ Files/Predoc_Standards_July2020.pdf. Accessed April 18, 2020.

15. OSCE. National Dental Examining Board of Canada-Bureau national d'examen dentaire du Canada. https://ndeb-bned.ca/en/ accredited/osce-examination. Accessed April 18, 2020.

16. Webster J, Hackley P. Teaching effectiveness in technologymediated distance learning. Acad Manage J. 1997;40:1282-1309.

17. Linjawi A. Present and future challenges for e-learning in dentistry [doctoral thesis]. Birmingham, UK: University of Birmingham; 2010.

18. Jordan J, Jalali A, Clarke S, Dyne P, Spector T, Coates W. Asynchronous vs didactic education: it's too early to throw in the towel on tradition. BMC Med Educ. 2013;13:105.
19. Gianoni-Capenakas S, Lagravere M, Pacheco-Pereira C, Yacyshyn J. Effectiveness and perceptions of flipped learning model in dental education: a systematic review. J Dent Educ. 2019;83(8): 935-945.

20. VoiceThread. https://voicethread.com/. Accessed April 18, 2020.

21. Kunin M, Julliard KN, Rodriguez TE. Comparing face-to-face, synchronous, and asynchronous learning: postgraduate dental resident preferences. J Dent Educ. 2014;78(6):856-866.

22. Molnar AL, Kearney RC. A comparison of cognitive presence in asynchronous and synchronous discussions in an online dental hygiene course. J Dent Hyg. 2017;91(3):14-21.

23. EDpuzzle. https://edpuzzle.com/. Accessed April 18, 2020.

24. August JN, Boyd LD, Giblin-Scanlon L. Bridging the theorypractice gap with dental hygiene instrumentation videos. J Dent Educ. 2018;82(9):961-967.

25. Canvas. https://www.instructure.com/canvas/. Accessed April 18, 2020.

26. ExamSoft. https://examsoft.com/. Accessed April 18, 2020.

27. ProctorU. https://www.proctoru.com/. Accessed April 18, 2020.

28. Honorlock. https://honorlock.com/. Accessed April 18, 2020.

29. Respondus Monitor: fully-automated proctoring for online exams. Respondus. https://web.respondus.com/he/monitor/. Accessed April 18, 2020.

30. Examity. https://examity.com/. Accessed April 18, 2020.

31. Turkyilmaz I, Hariri NH, Jahangiri L. Student's perception of the impact of E-learning on dental education. J Contemp Dent Pract. 2019;20(5):616-621.

32. ADA develops guidance on dental emergency, nonemergency care. American Dental Association. https://www.ada.org/en/ publications/ada-news/2020-archive/march/ada-developsguidance-on-dental-emergency-nonemergency-care. Accessed April 18, 2020.

33. Healthcare supply of personal protective equipment. Centers for Disease Control and Prevention. https://www.cdc.gov/ coronavirus/2019-ncov/hcp/healthcare-supply-ppe.html. Accessed April 18, 2020.

34. Wong JG, Cheung EP, Cheung V, et al. Psychological responses to the SARS outbreak in healthcare students in Hong Kong. Med Teach. 2004;26(7):657-659.

How to cite this article: Iyer P, Aziz K, Ojcius DM. Impact of COVID-19 on dental education in the United States. J Dent Educ. 2020;84:718-722. https://doi.org/10.1002/jdd.12163 